\title{
Increased Performance of Thermoplastic Packaging Materials by Using a Mild Oxidizing Biobased Additive
}

\author{
Ferdinand Männle, ${ }^{1}$ Jens Kjær Jørgensen, ${ }^{1}$ and Bjørn Steinar Tanem ${ }^{2}$ \\ ${ }^{1}$ SINTEF Materials and Chemistry, Synthesis and Properties, P.O. 124 Blindern, 0314 Oslo, Norway \\ ${ }^{2}$ SINTEF Materials and Chemistry, Synthesis and Properties, Høgskoleringen 5, 7491 Trondheim, Norway
}

Correspondence should be addressed to Ferdinand Männle, ferdinand.mannle@sintef.no

Received 15 November 2011; Revised 14 January 2012; Accepted 14 January 2012

Academic Editor: Sarat Kumar Swain

Copyright (C) 2012 Ferdinand Männle et al. This is an open access article distributed under the Creative Commons Attribution License, which permits unrestricted use, distribution, and reproduction in any medium, provided the original work is properly cited.

\begin{abstract}
Green additives such as prodegradants based on natural fatty acids and iron can improve the environmental profile of thermoplastic packaging materials. We present two studies in which this is demonstrated. In the first study, the addition of a green prodegradant to a 5-layer gas barrier laminate during processing provided a laminate with significantly reduced oxygen transmission due to the resulting oxygen-consuming degradation process. The result shows that material reduction and cost efficiency of packaging laminates can be combined, since 5-layer laminates with reduced oxygen barrier layer thickness and retained gas barrier properties are feasible. The products are interesting from an ecological and economic aspect. In the second study, the addition of a green prodegradant to several qualities of polypropylene that are used in packaging applications leads to materials that are readily degraded in accelerated weathering. The molecular weight of the modified polypropylenes after 830 hours of accelerated weathering is reduced from typically $80.000 \mathrm{~g} / \mathrm{mole}$ to $1.500-2.500 \mathrm{~g} / \mathrm{mole}$. At such molecular weight levels, digestion by microorganisms is feasible. The mild prodegradant used in the study does not lead to degradation during processing. Thermoplastics containing such additives are therefore fully recyclable provided that they have not been exposed to a long period of weathering.
\end{abstract}

\section{Introduction}

Thermoplastic packaging materials have in the past three decades faced an increasing demand to improve their environmental profile. As a consequence, significantly increased amounts of renewables have been used in packaging materials [1-8]. Additionally such materials often exhibit a green profile due to their biodegradability [9-11]. Reduced material consumption is also an important approach. Packaging materials with reduced wall thickness but preserved mechanical and/or gas barrier properties lead to reduced carbon footprint and combine environmental friendliness with cost efficiency. Another route to packaging materials with increased environmental profile is to establish effective recycling procedures. Littering should be significantly reduced if users are aware of the value of post-consumer packaging [12]. Conventional thermoplastic packaging materials can be turned into finally biodegradable materials by addition of prodegradant additives during processing into packaging products [13-15]. Prodegradants based on renewables such as fatty acid salts and environmentally friendly metals like iron are especially interesting. Thermoplastics containing such additives are fully recyclable [16].

In this paper we present the results of two studies in which green prodegradants based on ferric stearate are added to different thermoplastics. In the first study a green prodegradant is added to a 5-layer gas barrier laminate during processing in order to investigate changes of the oxygen transmission rate due to the presence of an oxygenconsuming degradation process. In the second study a green prodegradant is added to several qualities of polypropylene that are used in packaging applications. The goal is to investigate changes in tensile properties and molecular weight during accelerated weathering due to oxidative degradation. 


\section{Experimental}

2.1. Prodegradant Additive in 5-Layer Oxygen Barrier Film. In the first step a mixture of ferric(III) stearate and stearic acid was prepared which is the main prodegradant agent in both studies. The synthesis was conducted in an oilthermostat-controlled 50-litre double-mantle glass reactor having two dosing pumps, a mechanically powered steel stirrer, a glass-mantled thermometer, a distillation cooler, a bottom valve, and a connected membrane vacuum pump. In advance a solution of $11.3 \mathrm{~kg}$ (41.8 moles) of ferric chloride hexahydrate in $10.5 \mathrm{~L}$ water and $0.11 \mathrm{~L}$ concentrated hydrochloric acid was prepared to produce a $21.9 \mathrm{~kg}$ aqueous ferric chloride solution with about $10.6 \% \mathrm{w} / \mathrm{w}$ iron. To provide the fat-soluble organic compound $12.9 \mathrm{~kg}(45.3$ moles), stearic acid was melted in the reactor by adjusting the temperature of the oil thermostat to $190^{\circ} \mathrm{C}$. Then $0.18 \mathrm{~L}$ low-aromatic white spirit (mixture of hydrocarbons, Statoil AS, Norway) and $0.35 \mathrm{~L}$ water were added, and the pressure reduced to 200 mbar. By means of one of the dosing pumps $6.1 \mathrm{~kg}$ of the in-advance-prepared ferric chloride solution was added over a 50-minute period. By means of one of the dosing pump $10 \mathrm{~mL}$ per minute of a $1 \%$ aqueous hydrogen peroxide solution was added to maintain a modest but continuous foaming in the reactor. The addition of the aqueous ferric chloride solution was adjusted so that the amount of distilled water and hydrogen chloride approximately corresponded to the amount of aqueous ferric chloride added. After complete addition of aqueous ferric chloride solution, the mixture was boiled and distilled under continuous addition of $25 \mathrm{~mL}$ per minute $1 \%$ aqueous hydrogen peroxide solution. The amount of distilled water and hydrogen chloride was larger than the amount of $1 \%$ hydrogen peroxide solution resulting in a decreased portion of water in the reaction mixture. When the temperature of the reaction mixture had reached $115^{\circ} \mathrm{C}$, it was cooled to about $100^{\circ} \mathrm{C}$ and thereafter drained through the bottom valve into 100 litre of a $1 \%$ hydrogen peroxide solution. When the resulting gas development dropped off, the ironcontaining additive was filtered from the liquid phase. The iron-containing additive was then dispersed in $1 \%$ aqueous hydrogen peroxide solution at $60-70^{\circ} \mathrm{C}$ for 2 hours by means of a dispersing rod. The dispersed iron-containing additive was filtered from the aqueous phase and dried in a convection oven at $50^{\circ} \mathrm{C}$. The iron content was measured by total combustion to be $3.6 \% \mathrm{w} / \mathrm{w}$.

In the second step, the mixture of ferric(III) stearate and stearic acid was compounded in a Clextral double-screw extruder together with other additives and a polypropylene quality. The compounding conditions are listed in Table 1 and Table 2. The compound is called "masterbatch 1" $(\mathrm{MB} 1)$, and its functionality is to introduce the main prodegradant into the thermoplastics in the 5-layer laminate. The composition of MB 1 is shown in Table 3.

In order to hinder degradation during processing of the thermoplastics, which form the 5-layer laminate, a second masterbatch, "masterbatch 2" (MB 2), has to be added. MB 2 has been prepared in a way similar to that of $\mathrm{MB} 1$, and its composition is shown in Table 4.
TABle 1: Description of the Clextral extruder.

\begin{tabular}{lc}
\hline Extruder type & Clextral double-screw extruder \\
\hline Rotation frequency & $150\left[\mathrm{~min}^{-1}\right]$ \\
Feeding & $10[\mathrm{~g} / \mathrm{min}]$ \\
Dwell time & $2-3[\mathrm{~min}]$ \\
Heating zones & 12 \\
Temperature profile & see Table 2 \\
Outlet nozzle & Circular/diameter $4 \mathrm{~mm}$ \\
\hline
\end{tabular}

TABLE 2: Compounding conditions on the Clextral extruder.

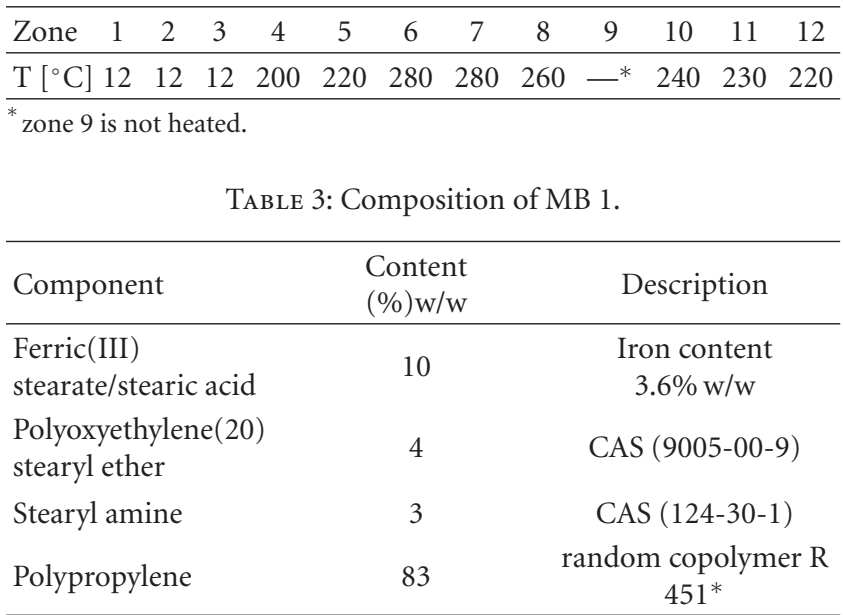

*Tiszai Vegyi Kombinát Plc., Hungary.

TABle 4: Composition of MB 2.

\begin{tabular}{|c|c|c|}
\hline Component & $\begin{array}{l}\text { Content } \\
(\%) \mathrm{w} / \mathrm{w}\end{array}$ & Description \\
\hline $\begin{array}{l}\text { Pentaerythritol Tetrakis } \\
\text { (3-(3,5-di-tert-butyl-4- } \\
\text { hydroxyphenyl) } \\
\text { propionylpentaerythriot) }\end{array}$ & 15 & $\begin{array}{c}\text { Irganox 1010, CAS } \\
{[6683-19-8]}\end{array}$ \\
\hline Polyethylene & 85 & $\begin{array}{l}\text { Linear low density (Exact } \\
\text { 0230, ExxonMobil, USA) }\end{array}$ \\
\hline
\end{tabular}

TABLE 5: Composition of the 5-layer laminate.

\begin{tabular}{lcc}
\hline Layer no. & Type of polymer & Description of polymer \\
\hline 1 & PE & Low-density polyethylene \\
2 & Modified PE & $\begin{array}{c}\text { Maleic-anhydride-modified PE } \\
\text { (OREVAC, Arkema, France) } \\
\text { Ethylene-vinyl alcohol }\end{array}$ \\
3 & EVOH & copolymer with 38\% mol \\
& & ethylene (Soarnol ET 3802, \\
& & Nippon Gohsei, Japan) \\
4 & Modified PE & $\begin{array}{c}\text { Maleic-anhydride-modified PE } \\
\text { (OREVAC, Arkema, France) }\end{array}$ \\
5 & PE & Low-density polyethylene \\
\hline
\end{tabular}

A 5-layer barrier film has been manufactured by 5-layer film blowing. The materials that constitute the 5 layers are listed in Table 5. 
TABLE 6: Description of the polypropylene qualities.

\begin{tabular}{lcc}
\hline PP quality & Manufacturer & Typical application area \\
\hline BE 170 MO & Borealis, Belgium & Injection moulding \\
Tipplen H 681 & TVK Plc., Hungary & Extrusion thermoforming \\
Tipplen K 948 & TVK Plc., Hungary & Injection moulding \\
Tipplen K299 & TVK Plc., Hungary & Injection moulding \\
Tipplen H 649 & TVK Plc., Hungary & Bisoriented film \\
\hline
\end{tabular}

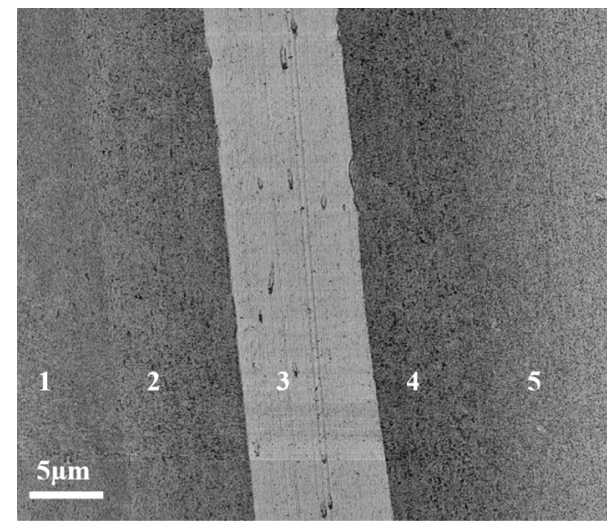

Figure 1: AFM characterization of 5-layer laminate.

The processing temperature was $190^{\circ} \mathrm{C}-230^{\circ} \mathrm{C}$. The total thickness of the laminate was $60 \mu \mathrm{m}$. Two different amounts of a 9:1 blend of MB 1/MB 2 have been added to all layers during processing. The total addition was $1 \%$ and $2 \% \mathrm{w} / \mathrm{w}$.

The oxygen transmission rate of the laminate was measured on an Ox-Tran device (MOCON Inc., USA) at $23^{\circ} \mathrm{C}$ and $50 \%$ relative humidity.

Atomic force microscopy was used to characterize the 5-layer laminate. Ultramicrotomy was used to cut the films perpendicular to the laminate plains and in the extrusion direction.

2.2. Prodegradant Additive in Polypropylene Qualities. the second part of the study, a prodegradant additive was compounded into five different polypropylene qualities (Table 6) and their degradability was investigated. Atomic force microscopy (AFM) shows the different layers and regularly distributed spots of the prodegradant additive (Figure 1).

The prodegradant additive was prepared in the same way as described in the first study, however with a different content of iron. The synthesis was carried out in order to obtain a mixture of ferric(III) stearate and stearic acid with an iron content of $1.9 \% \mathrm{w} / \mathrm{w}$. This mixture was compounded in a Clextral double-screw extruder together with other additives and a polypropylene quality in order to obtain the prodegradant masterbatch for the second study. The obtained masterbatch is called "masterbatch 3" (MB 3), and its composition is shown in Table 7.

Similar to the first study, a 9:1 blend of $\mathrm{MB} 3 / \mathrm{MB}$ 2 has been added to the polypropylene qualities during processing. The extruded tape samples were fixed to suitable
TABle 7: Composition of MB 3.

\begin{tabular}{lcc}
\hline Component & $\begin{array}{l}\text { Content } \\
(\%) w / w\end{array}$ & Description \\
\hline $\begin{array}{l}\text { Ferric(III) stearate/stearic } \\
\text { acid }\end{array}$ & 16 & Iron content $1.9 \% \mathrm{w} / \mathrm{w}$ \\
$\begin{array}{l}\text { Polyoxyethylene(10) } \\
\text { stearyl ether }\end{array}$ & 8 & CAS $(9005-00-9)$ \\
$\begin{array}{l}\text { Stearyl amine } \\
\text { Polypropylene }\end{array}$ & 5 & CAS (124-30-1) \\
${ }^{*}$ Tiszai Vegyi Kombinát Plc., Hungary. &
\end{tabular}

TABLE 8: SEC conditions.

\begin{tabular}{lc}
\hline Instrument type & PL-GPC 210 \\
\hline Columns type & $4^{*}$ PL gel 20 micron LS \\
Solvent & $1,2,4$-trichloro benzene \\
Temperature & $145^{\circ} \mathrm{C}$ \\
Injection volume & $0.20 \mathrm{~mL}$ \\
Sample concentration & $2-3 \mathrm{mg} / \mathrm{mL}$ \\
Calibration & Polystyrene standards \\
Mark Houwink constants & $K=14.1 * 10^{-4} \mathrm{dL} / \mathrm{g}, a=0.7$ \\
\hline
\end{tabular}

TABle 9: Oxygen transmission rate and elongation at break of the 5-layer laminate.

\begin{tabular}{lcccc}
\hline $\begin{array}{l}\text { Thickness of } \\
\text { EVOH layer }\end{array}$ & MB 1 & MB 2 & $\begin{array}{c}\text { OTR } \\
\left(\mathrm{cm}^{3} \mathrm{O}_{2} / \mathrm{m}^{2 *} \text { day }\right)\end{array}$ & $\begin{array}{c}\text { Elongation at } \\
\text { break (\%) }\end{array}$ \\
\hline $5 \mu \mathrm{m}$ & $0.9 \%$ & $0.1 \%$ & $2,12 \pm 0.03$ & $355 \pm 55$ \\
$5 \mu \mathrm{m}$ & $1.8 \%$ & $0.2 \%$ & $1,51 \pm 0.03$ & $318 \pm 6$ \\
$10 \mu \mathrm{m}$ & $0 \%$ & $0 \%$ & $3 \pm 0.5^{*}$ & - \\
$5 \mu \mathrm{m}$ & $0 \%$ & $0 \%$ & $5 \pm 1.0^{*}$ & - \\
\hline
\end{tabular}

* Information from technical datasheet (Nippon Gohsei).

specimen holders (Atlas Electric Devices Company, Illinois, USA) and exposed for accelerated weathering in an UVCON WEATHER-O-METER (Atlas Electric Devices Company, Illinois, USA). The accelerated weathering device is equipped with 340 UVA fluorescent lamps and is suitable for testing procedures according to ISO 4892-3 (ASTM G154). The periodic testing cycle consisted of the following procedures:

(i) 4 hours of dry UV exposure with 340 UVA fluorescent lamps at $60^{\circ} \mathrm{C}$,

(ii) 0.5 hours of water spay with deionized water at $8-$ $10^{\circ} \mathrm{C}$,

(iii) 3.5 hours of condensation $40^{\circ} \mathrm{C}$.

Degradation of the tape samples was followed by mechanical testing (ISO 527-2) and finally by SEC analysis. SEC was performed according to ISO 16014-1, 16014-2, and 16014-4. As specified in Table B.1 in ISO 16014-2, the same Mark Houwink constant was used for the polypropylene samples and the polystyrene standards. The SEC conditions are listed in Table 8. 
TABLE 10: Elongation at break (\%) depending on accelerated weathering time.

\begin{tabular}{|c|c|c|c|c|c|c|}
\hline PP quality & Sum MB 2/MB 3 & $\begin{array}{c}\text { Accel. } \\
\text { weathering } \\
0 \text { hours }\end{array}$ & $\begin{array}{c}\text { Accel. } \\
\text { weathering } \\
24 \text { hours }\end{array}$ & $\begin{array}{c}\text { Accel. } \\
\text { weathering } \\
48 \text { hours }\end{array}$ & $\begin{array}{c}\text { Accel. } \\
\text { weathering } \\
72 \text { hours }\end{array}$ & $\begin{array}{c}\text { Accel. } \\
\text { weathering } \\
96 \text { hours }\end{array}$ \\
\hline $\mathrm{BE} 170 \mathrm{MO}$ & $2 \% \mathrm{w} / \mathrm{w}$ & $12 \pm 3$ & $<5$ & $<2$ & - & - \\
\hline Tipplen H 681 & $2 \% \mathrm{w} / \mathrm{w}$ & $349 \pm 346$ & $5 \pm 3$ & $6 \pm 4$ & $<5$ & $<2$ \\
\hline Tipplen K 948 & $2 \% \mathrm{w} / \mathrm{w}$ & $23 \pm 8$ & $<5$ & $<2$ & - & - \\
\hline Tipplen K299 & $2 \% \mathrm{w} / \mathrm{w}$ & $7 \pm 3$ & $<5$ & $<2$ & - & - \\
\hline Tipplen H 649 & $1 \% \mathrm{w} / \mathrm{w}$ & $710 \pm 94$ & $700 \pm 87$ & $23 \pm 32$ & $<5$ & $<2$ \\
\hline Tipplen H 649 & $0 \% \mathrm{w} / \mathrm{w}$ & $475 \pm 314$ & $706 \pm 54$ & $650 \pm 94$ & $676 \pm 104$ & $584 \pm 76$ \\
\hline
\end{tabular}

TABLE 11: Strain at yield $\left(\mathrm{N} / \mathrm{mm}^{2}\right)$ depending on accelerated weathering time.

\begin{tabular}{|c|c|c|c|c|c|c|}
\hline PP quality & Sum MB 2/MB 3 & $\begin{array}{c}\text { Accel. } \\
\text { weathering }\end{array}$ & $\begin{array}{c}\text { Accel. } \\
\text { weathering }\end{array}$ & $\begin{array}{c}\text { Accel. } \\
\text { weathering }\end{array}$ & $\begin{array}{c}\text { Accel. } \\
\text { weathering }\end{array}$ & $\begin{array}{c}\text { Accel. } \\
\text { weathering }\end{array}$ \\
\hline & & 0 hours & 24 hours & 48 hours & 72 hours & 96 hours \\
\hline BE $170 \mathrm{MO}$ & $2 \% \mathrm{w} / \mathrm{w}$ & $29.3 \pm 1.1$ & $5.6 \pm 3.9$ & $1.7 \pm 0.5$ & - & - \\
\hline Tipplen H 681 & $2 \% \mathrm{w} / \mathrm{w}$ & $27.9 \pm 3.1$ & $17.3 \pm 4.2$ & $14.9 \pm 2.1$ & $<10$ & $<5$ \\
\hline Tipplen K 948 & $2 \% \mathrm{w} / \mathrm{w}$ & $21.6 \pm 0.7$ & $<10$ & $<5$ & - & 一 \\
\hline Tipplen K299 & $2 \% \mathrm{w} / \mathrm{w}$ & $19.7 \pm 1.7$ & $2.7 \pm 0.4$ & $2.4 \pm 1.6$ & - & 一 \\
\hline Tipplen H 649 & $1 \% \mathrm{w} / \mathrm{w}$ & $35.0 \pm 4.6$ & $33.0 \pm 3.7$ & $20.0 \pm 3.2$ & $<10$ & $<5$ \\
\hline Tipplen H 649 & $0 \% \mathrm{w} / \mathrm{w}$ & $29.9 \pm 3.4$ & $35.2 \pm 3.0$ & $32.8 \pm 3.1$ & $31.4 \pm 2.7$ & $32.5 \pm 3.5$ \\
\hline
\end{tabular}

\section{Results and Discussion}

3.1. Prodegradant Additive in 5-Layer Oxygen Barrier Film. Table 9 shows the results on oxygen transmission rate (OTR) and elongation at break (ISO 527-2) of the 5-layer laminate. Elongation at break was taken as an average of 10 samples.

The results show that the oxygen transmission rate is significantly improved by addition of the prodegradant additive. This can be explained by the oxygen consumption of a slow degradation process in the laminate which is induced by the prodegradant additive.

Doubling of the amount of prodegradant additive does not induce significant degradation during processing and short storage. Elongation at break is a very sensitive marker for ongoing degradation. The very narrow result distribution of elongation at break (low standard deviation) shows that the adhesion within the layers after addition of $2 \%$ of prodegradant additive is excellent and significantly better than with lower amounts.

Atomic force microscopy (AFM) shows the different layers and regularly distributed spots of the prodegradant additive. This is in good compliance with an oxygen-consuming slow degradation process around the prodegradant additive.

As a consequence, 5-layer laminates with reduced oxygen barrier layer thickness and retained gas barrier properties are feasible. This is interesting from an ecological aspect (material reduction) and economical aspect (cost reduction).

3.2. Prodegradant Additive in Polypropylene Qualities. Mechanical properties of $0.4 \mathrm{~mm}$ tape samples based on the different polypropylene qualities after different periods of accelerated weathering are shown below. Elongation at break is listed in Table 10 and strain at yield is listed in Table 11.

A comparison of the mechanical properties elongation at break and strain at yield of polypropylene qualities with and without prodegradant indicates clearly that qualities with prodegradant do not suffer significant degradation during processing. The development of the mechanical properties also shows that all of the five PP qualities with prodegradant additive degrade rapidly when they are exposed to accelerated weathering. The typical mechanical properties of PP materials are lost after 72 hours of accelerated weathering. In some cases the majority of samples became too brittle due to proceeded degradation. Therefore accurate data on elongation at break or strain at yield could not be obtained. When the data are based on one or two samples, the values are expressed as "<(number)". When all samples became too brittle, the expression “__” was used.

Additionally the molecular weight distribution of the PP qualities after 830 hours of accelerated weathering was measured by SEC. The results are listed in Table 12 .

SEC analysis clearly indicates that the degradation of the five PP qualities with prodegradant additive continues after the loss of the typical mechanical properties. The average molecular weight of the modified polypropylenes after 830 hours of accelerated weathering is reduced from typically $80.000 \mathrm{~g} / \mathrm{mole}$ to $1.500-2.500 \mathrm{~g} / \mathrm{mole}$. At these values average molecular weight levels are small enough to make the degraded PP qualities accessible for biodegradation. 
TABLE 12: SEC average molecular weights $M_{w}$ and $M_{n}$ and polydispersity $\left(M_{w} / M_{n}\right)$ after 830 hours of accelerated weathering.

\begin{tabular}{lcccc}
\hline PP quality & $\begin{array}{c}\text { Sum MB } \\
\text { 2/MB 3 }\end{array}$ & $\mathrm{M}_{n}$ & $\mathrm{M}_{w}$ & $\begin{array}{c}\text { Polymer } \\
\text { dispersity }\end{array}$ \\
\hline BE 170 MO & $2 \% \mathrm{w} / \mathrm{w}$ & $919 \pm 10$ & $2518 \pm 30$ & $2,7 \pm 0,06$ \\
Tipplen H 681 & 2\% w/w & $695 \pm 12$ & $1554 \pm 41$ & $2,2 \pm 0,02$ \\
Tipplen K 948 & 2\% w/w & $807 \pm 16$ & $1864 \pm 44$ & $2,3 \pm 0,01$ \\
Tipplen K299 & 2\% w/w & $767 \pm 0$ & $1752 \pm 8$ & $2,3 \pm 0,01$ \\
Tipplen H 649 & 1\% w/w & $707 \pm 24$ & $1572 \pm 50$ & $2,2 \pm 0,00$ \\
\hline
\end{tabular}

\section{Summary}

Green additives such as prodegradants based on natural fatty acids and iron can improve the environmental profile of thermoplastic packaging materials. Reduced oxygen transmission rate of a 5-layer gas barrier laminate was observed and explained by the oxygen consumption of a slow degradation process in the laminate. The result shows that material reduction and cost efficiency of packaging laminates can be combined, since 5-layer laminates with reduced oxygen barrier layer thickness and retained gas barrier properties are feasible. The products are interesting from an ecological and economic aspect.

Additionally several qualities of polypropylene which are used in packaging applications are degraded in accelerated weathering to an extent which makes digestion by microorganism feasible. Mild prodegradant based on ferric stearate does not lead to degradation during processing. Thermoplastics containing such additives are fully recyclable, provided that they have not been exposed to a long period of weathering.

\section{Acknowledgments}

The authors thank the Research Council of Norway for grants received in the Projects 169735, 176212, and 182619. Furthermore, the authors thank Nor-X Industry AS for supplying sample materials and organizing a full-scale trial for the production of the 5-layer laminate. Finally, the authors thank Tiszai Vegyi Kombinát for providing several stabilized and unstabilized polypropylene qualities.

\section{References}

[1] J. M. Saiter, L. Dobircau, and N. Leblanc, "Are 100\% green composites and green thermoplastics, the new materials for the future," International Journal of Polymer Science, vol. 2012, Article ID 280181, 7 pages, 2012.

[2] R. L. Quirino and R. C. Larock, "Bioplastics, biocomposites, and biocoatings from natural oils," in Renewable and Sustainable Polymers, vol. 1063 of ACS Symposium Series, pp. 37-59, 2011.

[3] "Advanced green composites and nanocomposites: new industrial biomaterials from biorefinery," in Design, Manufacturing and Applications of Composites, A. K. Mohanty, S. Vivekanandhan, S. Sahoo, M. N. Misra, and D. Anh, Eds., vol. 2010 of Proceedings of the 8th Joint Canada-Japan Workshop on Composites, pp. 3-7, Boucherville, Canada, July 2010.

[4] A. P. Ambekar, P. Kukade, V. Mahajan, and A. D. Ngo, "Bioplastics: a solution," Popular Plastics \& Packaging, vol. 55, no. 9, pp. 30-32, 2010.

[5] D. Marjadi, N. Dharaiya, and A. D. Ngo, "Bioplastic: a better alternative for sustainable future," Everyman's Science, vol. 45, no. 2, pp. 90-92, 2010.

[6] H. H. Khoo, R. B. H. Tan, and A. D. Ngo, "Environmental impacts of conventional plastic and bio-based carrier bags," International Journal of Life Cycle Assessment, vol. 15, no. 4, pp. 338-345, 2010.

[7] F. Gironi and V. Piemonte, "Life cycle assessment of polylactic acid and polyethylene terephthalate bottles for drinking water, Environmental Progress \& Sustainable Energy, vol. 30, no. 3, pp. 459-468, 2011.

[8] J. Rincones, A. F. Zeidler, M. C. B. Grassi, M. F. Carazzolle, and G. A. G. Pereira, "The golden bridge for nature: the new biology applied to bioplastics," Polymer Reviews, vol. 49, no. 2, pp. 85-106, 2009.

[9] R. Nanda, A. Sasmal, J. Panigrahi, and P. L. Nayak, "Plastic from bacteria: a new technology for the twenty first century," Popular Plastics \& Packaging, vol. 54, no. 6, pp. 21-28, 2009.

[10] R. Haque, M. Saxena, B. Yadav, and M. Ahmed, "Production and current applications of biodegradable polymer polylactide (PLA): a review," Journal of Environmental Research and Development, vol. 3, no. 1, pp. 257-268, 2008.

[11] R. A. J. Verlinden, D. J. Hill, M. A. Kenward, C. D. Williams, and I. Radecka, "Bacterial synthesis of biodegradable polyhydroxyalkanoates," Journal of Applied Microbiology, vol. 102, no. 6, pp. 1437-1449, 2007.

[12] http://www.plasticseurope.org/plastics-sustainability/marinelitter.aspx.

[13] E. Chiellini, A. Corti, and S. D'Antone, "Pro-degradant full carbon backbone polymers-biodegradation behaviour of thermally oxidized polyethylene in an aqueous medium," Polymer Degradation and Stability, vol. 92, no. 7, pp. 13781383, 2007.

[14] E. Chiellini, A. Corti, and G. Swift, "Biodegradation of thermally-oxidized, fragmented low-density polyethylenes," Polymer Degradation and Stability, vol. 81, no. 2, pp. 341-351, 2003.

[15] A. Krzan, S. Hemjinda, S. Miertus, A. Corti, and E. Chiellini, "Standardization and certification in the area of environmentally degradable plastics," Polymer Degradation and Stability, vol. 91, no. 12, pp. 2819-2833, 2006.

[16] Å. Larsen and E. A. Kleppe, "Recycling plastics with Nor$\mathrm{X}$ degradable in full-scale industrial recycling process," in IdentiPlast, Brussels, Belgium, 2007. 

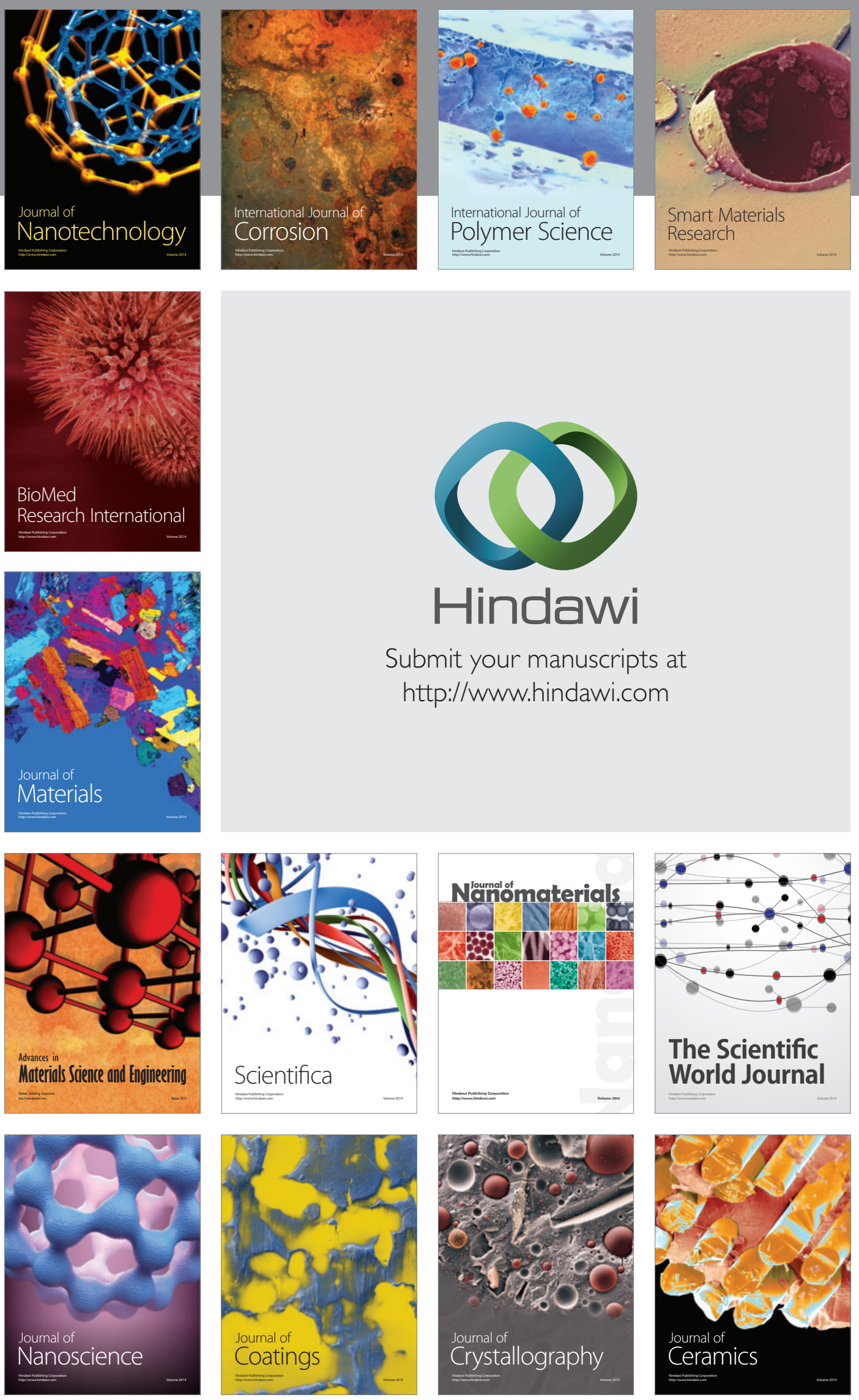

The Scientific World Journal

Submit your manuscripts at

http://www.hindawi.com

\section{World Journal}

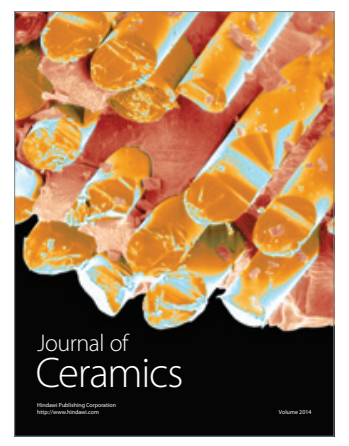

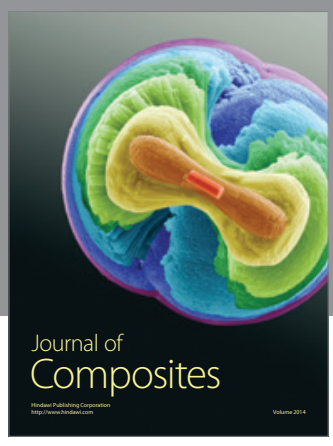
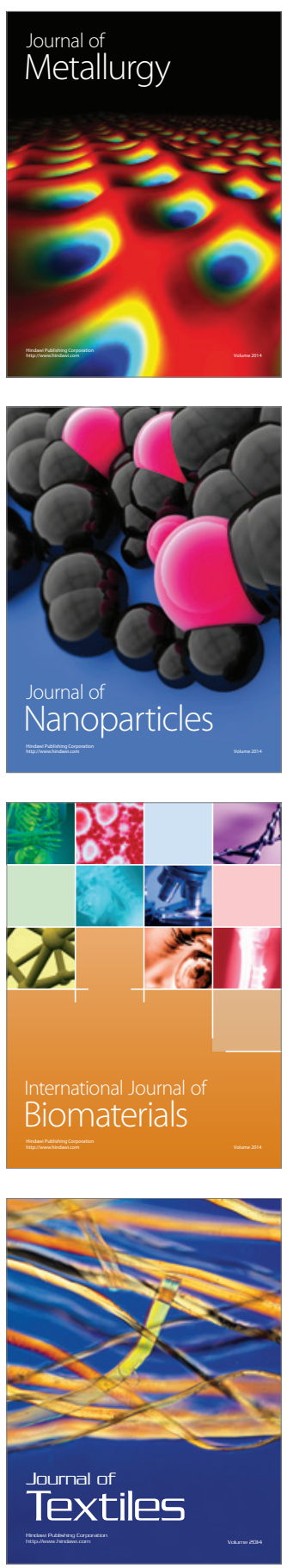